\title{
COMPARISON OF STAND STRUCTURE IN MANAGED AND VIRGIN EUROPEAN BEECH FORESTS IN SERBIA
}

\section{USPOREDBA STRUKTURE SASTOJINA GOSPODARENIH I PRAŠUMSKIH BUKOVIH ŠUMA SRBIJE}

\author{
Bratislav MATOVIĆ ${ }^{1}$, Miloš KOPRIVICA², Bratislav KISIN³, Dejan STOJANOVIĆ4 ${ }^{4}$ Igor KNEGINJIĆ5 \\ Stefan STJEPANOVIĆ6
}

\begin{abstract}
Summary
This study presents results of the comparison of structural and production characteristics of managed and virgin European beech forests in Serbia. Five managed and three virgin European beech stands were studied. The aim of this research was to determine the impact of the previous forest management on the structural diversity and production characteristics of managed European beech high forests in Serbia. The observed stands are located in the mountainous range of 400 to 1200 meters above sea level in the areas with the most productive beech forests in Serbia. Structural characteristics were compared using the following parameters: Height curves, Diameter distribution, Gini index, Coefficient of variation, Slenderness coefficient and maximum dimensions of standing living and dead trees. Stand density and productive characteristics were studied using the following forest estimation elements: number of trees, basal area, volume, biomass, carbon stock, stand quadratic mean diameter, Lorey's mean height and volume of dead wood. The greatest differences were found in the dimensions of the largest trees in managed and virgin beech forests (diameters at breast height and heights). Certain differences were found in the shape of Height curves and Diameter distribution and in the values of Slenderness coefficient. However, the Gini index and the Coefficient of variation show that these managed beech forests in Serbia substantially preserve the primeval structural diversity. The differences in the average value of most forest estimation elements of managed beech high forests in Serbia compared to virgin beech forests are statistically significant, which tells us that the previous management had a significant impact on the changes in the production characteristics of these forests in Serbia.
\end{abstract}

KEY WORDS: Fagus sylvatica, forest management, virgin forest, the Balkans

\section{INTRODUCTION}

\section{UVOD}

In the last decades, the terms "close-to-nature forestry", "nature-based forestry", "near-natural forestry", "continuous cover forestry", "multi-aged forestry", "green-tree retention", "nature-oriented silviculture", "naturalistic silviculture" or "ecological silviculture" have been increasingly used in forest management (Schütz 1986, Franklin 1989, Benecke 1996, Mlinšek 1996, Yorke 1998, von Gadow et al. 2002, Pommerening \& Murphy 2004). Most of these terms refer

\footnotetext{
${ }^{1}$ Dr. Bratislav Matović, University of Novi Sad, Institute of Lowland Forestry and Environment, Serbia, and University of East Sarajevo, Faculty of Agriculture, Republic of Srpska, BIH, bratislav.matovic@uns.ac.rs

2 Dr. Miloš Koprivica, Faculty of Forestry, Banja Luka, Republic of Srpska, BIH, koprivica.milos@gmail.com

${ }^{3}$ Dr. Bratislav Kisin, State Enterprise for Forest Management "Srbijašume", Belgrade, Serbia, bratislav.kisin@srbijasume.rs

${ }^{4}$ Dr. Dejan Stojanović, University of Novi Sad, Institute of Lowland Forestry and Environment, Novi Sad, Serbia, dejan.stojanovic@uns.ac.rs

${ }^{5}$ MSc Igor Kneginjić, Public Enterprise "Šume RS" ad Sokolac, Republic of Srpska BiH

${ }^{6}$ MSc Stefan Stjepanović, University of East Sarajevo, Faculty of Agriculture, Republic of Srpska, BlH, stefan.stjepanovicuis@gmail.com
} 
to a forest management approach which generally includes management of "continuous forests" with management systems that don't require radical silvicultural measures but silvicultural measures which "imitate nature and improve its performance" (Schütz 1986). Close-to-nature forestry is characterized by some fundamental features such as natural regeneration, single-tree felling, indigenous tree species, etc. One of the systems that can be attributed to close-tonature forestry and which is applied in Europe is selection system. The concept of close-to-nature forestry is relatively old and could be traced back to the works of Gayer (1886) and Möller (1922).

Furthermore, close-to-nature forestry has recently become one of the most important ways of ensuring sustainable management of European forests (Bradshaw et al. 1994, Meyer 2005). According to Schnitzler \& Borlea (1998), sustainable management of natural forests depends on two complementary parts: a) protection of the remaining forests with a high degree of naturalness and b) establishment of the management criteria which take into account the natural dynamics of the forests. "Continuous forest" together with an increase in the stand mixture is becoming one of the primary approaches to the present and future forest management in Europe.

Most Balkan countries (Slovenia, Bosnia and Herzegovina, Serbia, Montenegro, Macedonia, Albania and partially Croatia) have been applying group selection and selection systems in the management of beech forests. Furthermore, most managed European beech forests in the Balkans have been applying "continuous forest" principle which has preserved their naturalness to a large extent.

Reliable knowledge of natural forest structure and dynamics is required if we want to implement close-to-nature forestry (Leibundgut 1959, Korpel 1995). Therefore, research of virgin forests (old-growth forests, primary forests, primeval forests, etc.) has recently received great importance (Diaci et al. 1999, Drössler \& Lüpke 2007). Since all Balkan countries have a much higher percentage of virgin forest stands than other European countries, they make an important area of future research. Some of these stands are protected by different protection regimes. However, significant areas of virgin forest stands can be found in rugged mountainous terrains in the regions with no formal protection.

Beech is the most abundant tree species in Serbia. It occurs in several forest monodominant or polydominant communities. According to Koprivica et al. (2013a) at the beginning of the twentieth century, beech forests in Serbia were predominantly virgin forests. From the beginning of the twentieth century until the 1960s, the main form of management was selection system. Afterwards, the group selection system was prescribed until the 1990s. In the last twenty years shelter-wood system is declaratively prescribed but rarely implemented in practice. Generally, there are apparent discrepancies between forest management plans and their implementation.

Selection and group selection systems which often favour felling of higher-quality trees have been the most commonly applied systems in the forestry practice of beech forests in Serbia in the last 70 years. The application of different management systems has caused heterogenic structure of beech high forests in Serbia. Today, these forests are characterized by unfavorable qualitative and assortment structure, although they have relatively high production potential, structural diversity and degree of naturalness. By using different indices, Matović (2012) concludes that these forests have very pronounced alpha ecosystem diversity which is caused by the differentiation in the size and age of trees and by their spatial distribution.

For future management of beech high forests in Serbia, it is important to conduct a thorough examination of their managed and virgin stands and make a comparison of their structural and production characteristics. Research of beech virgin forest is important in the European context because of their rare frequency. Meyer (2005) notes that it is important for the Central European forestry to thoroughly explore virgin forest stands because larger areas of these stands can only be found in the mountains of eastern and southern Europe.

So far structural and production characteristics of beech virgin forest have been studied in eastern and central Europe (Mayer \& Reimoser 1978, Leibundgut 1993, Korpel 1995, Commarmot et al. 2005, Turcu \& Stetca, 2006, Drössler \& Lüpke, 2007, Bilek et al. 2011, Kucbel et al. 2012, Petritan et al. 2012), but not in the Balkans. In the Balkans, beech virgin forests were studied in the period from the thirties to the seventies of the twentieth century (Miletić 1930, Milin 1954, Drinić 1957). Recent studies are rare (Leibundgut 1993, Meyer 2003).

The aims of this research were to compare structural and production characteristics of managed and virgin beech forests in Serbia in order to determine:

1) The impact of the previous forest management on the structural diversity of beech high forests in Serbia which represents an important segment of the overall diversity of these forests;

2) The impact of previous forest management on the changes in the production characteristics of managed beech high forests in Serbia.

Also, in order to enhance the understanding of the similarities and differences in structural and production characteristics of virgin forests in a wider context, we have made a comparative analysis of the results published for these forests in Central, Eastern and Southern Europe. 


\section{MATERIAL AND METHODS}

\section{MATERIJAL I METODE}

\section{Study area - Područje istraživanja}

The research was conducted in managed and virgin beech forests with similar production potential. The study area included five managed stands (33a - Homoljske planine, 122a - Istočna Boranja, 27a - Zapadna Boranja, 31a - Čemernik-Ostrozub and 44a - Željin) and three virgin forest stands (Danilova kosa, Vinatovača and Kukavica) on the most productive sites in Serbia (Fig. 1).

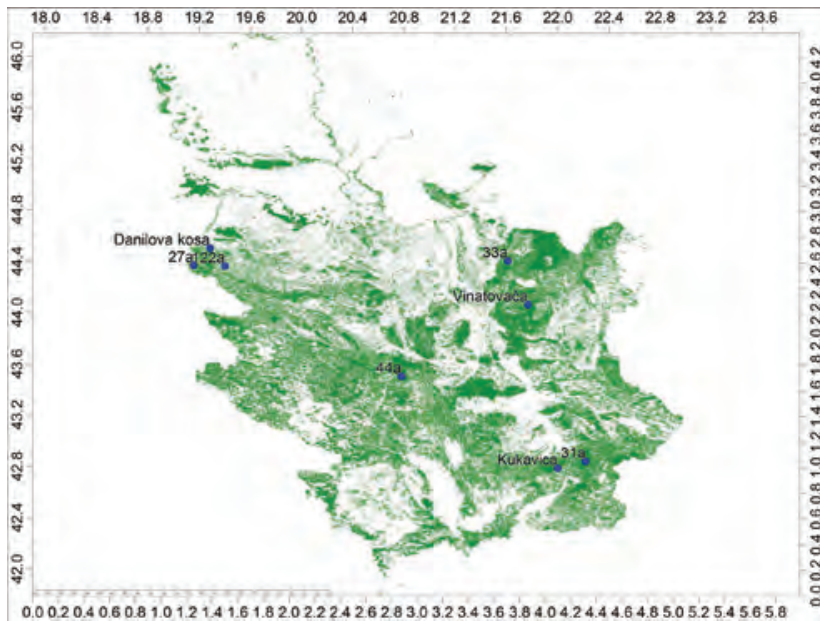

Figure 1. Locations of the studied forest stands in Serbia Slika 1. Lokacije istraživanih sastojina u Srbiji
General characteristics of the studied European beech stands are presented in Table 1.

The observed stands have similar production potential (classes I to II, Mirković 1969) but they differ in stand characteristics. They are located in the mountainous range of 400 to 1200 meters above sea level which is the zone where monodominant beech forests in Serbia are widespread. The share of other tree species in the volume was about 0 to $1 \%$. According to historical management plans, in studied managed stands applied were selection and group selection systems in last 40-50 years. All three virgin forests have been declared strict nature reserves by Serbian Government (Danilova kosa in 1950; Vinatovača in 1957 and Kukavica in 1980). However, even before the protection of these stands was declared, there had been no intensive management treatments.

\section{Data collection - Prikupljanje podataka}

Systematic sampling was used for the purpose of data gathering and processing in the managed stands. Circular sample plots of 0.05 ha in size, at a distance of $100 \times 100 \mathrm{~m}$ (one plot represents one hectare) were set. Diameter at breast height (dbh) and tree heights (h) were measured in all test areas. Two cross diameters were taken. The height of trees was measured using Vertex 3 clinometer. In two virgin forests stands (Danilova kosa and Vinatovača) all trees had their diameters and heights (total survey) measured, while a set of seven square and rectangular experimental fields of

Table 1. Characteristics of the studied beech stands

Tablica 1. Karakteristike istraživanih bukovih sastojina

\begin{tabular}{|c|c|c|c|c|c|c|c|c|}
\hline \multirow{2}{*}{$\begin{array}{l}\text { General } \\
\text { characteristics }\end{array}$} & \multicolumn{8}{|c|}{ Stand } \\
\hline & $33 a$ & $122 a$ & $27 a$ & $31 \mathrm{a}$ & $44 a$ & Danilova kosa & Vinatovača & Kukavica \\
\hline Latitude [ $\left.{ }^{\circ} \mathrm{N}\right]$ & $44^{\circ} 24^{\prime} 05^{\prime \prime}$ & $44^{\circ} 21^{\prime} 38^{\prime \prime}$ & $44^{\circ} 22^{\prime} 04^{\prime \prime}$ & $42^{\circ} 50^{\prime} 15^{\prime \prime}$ & $43^{\circ} 30^{\prime} 02^{\prime \prime}$ & $44^{\circ} 22^{\prime} 01^{\prime \prime}$ & $44^{\circ} 03^{\prime} 36^{\prime \prime}$ & $42^{\circ} 47^{\prime} 02^{\prime \prime}$ \\
\hline Longitude $\left[{ }^{\circ} \mathrm{E}\right]$ & $21^{\circ} 36^{\prime} 32^{\prime \prime}$ & $19^{\circ} 16^{\prime} 44^{\prime \prime}$ & $19^{\circ} 09^{\prime} 23^{\prime \prime}$ & $22^{\circ} 12^{\prime} 55^{\prime \prime}$ & $20^{\circ} 46^{\prime} 43^{\prime \prime}$ & $19^{\circ} 16^{\prime} 58^{\prime \prime}$ & $21^{\circ} 46^{\prime} 00^{\prime \prime}$ & $21^{\circ} 59^{\prime} 51^{\prime \prime}$ \\
\hline Altitude (m) & $400-540$ & $690-830$ & $480-630$ & $880-1060$ & $1000-1170$ & $670-760$ & $630-870$ & $670-1175$ \\
\hline Area (ha) & 22.7 & 29.5 & 20.2 & 31.6 & 22.6 & 6.73 & 27.6 & 76.2 \\
\hline Number of plots & 23 & 29 & 20 & 32 & 23 & 1 & 1 & 7 \\
\hline Plot size [ha] & 0.05 & 0.05 & 0.05 & 0.05 & 0.05 & 6.73 & 27.6 & $0.15-0.79$ \\
\hline $\begin{array}{l}\text { Number of } \\
\text { measured trees }\end{array}$ & 315 & 310 & 259 & 482 & 340 & 831 & 4833 & 529 \\
\hline Temperature* & 8.6 & 7.6 & 8.7 & 6.9 & 6.7 & 8.1 & 7.3 & 7.7 \\
\hline Precipitation* & 712 & 1023 & 947 & 967 & 970 & 997 & 716 & 861 \\
\hline $\mathrm{EQ}^{* *}$ & 26.0 & 16.1 & 18.8 & 16.0 & 15.9 & 17.1 & 24.0 & 19.5 \\
\hline Bedrock & Limestone & Granodior. & Schist & Gneiss & Granite & Granodior. & Schist & Gneiss \\
\hline Soil type & $\begin{array}{l}\text { Calco } \\
\text { cambisol }\end{array}$ & $\begin{array}{l}\text { Dystric } \\
\text { cambisol }\end{array}$ & Luvisol & $\begin{array}{l}\text { Dystric } \\
\text { cambisol }\end{array}$ & $\begin{array}{l}\text { Dystric } \\
\text { cambisol }\end{array}$ & $\begin{array}{l}\text { Dystric } \\
\text { cambisol }\end{array}$ & $\begin{array}{l}\text { Dystric } \\
\text { cambisol }\end{array}$ & $\begin{array}{l}\text { Dystric } \\
\text { cambisol }\end{array}$ \\
\hline Site class ${ }^{* * *}$ & ॥ & $1 / I I$ & $\|$ & II & I/II & 1 & $\|$ & $1 / I I$ \\
\hline
\end{tabular}

*Mean annual temperature and sum of precipitation (Republic Hydrometeorological Service of Serbia) interpolated by kriging method for specific sites.

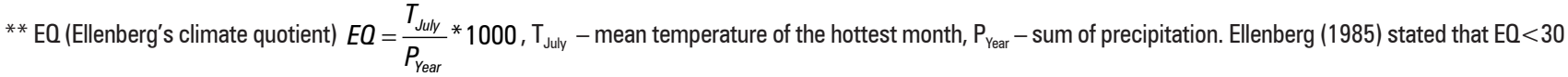
is the beech distribution limit in Central Europe. Stojanović et al. (2013) confirmed that these values are relevant for the region of Serbia.

*** Site classes are defined according to dominant height and comparison with sets of standard height curves Mirković (1969). Sets has 9 site classes and inter-classes (I- the best; $\mathrm{V}$ - the worst). 
different size were established in Kukavica virgin forest for the purpose of these measurements. Trees with $\mathrm{dbh}>10 \mathrm{~cm}$ were measured in all stands. In the beech virgin forests within the same area, the volume of lying and standing dead wood was estimated and compared with the results on managed forests obtained and published by Koprivica et al. (2013a). We measured standing dead wood with dbh above $10 \mathrm{~cm}$ and all parts of lying dead wood thicker than $3 \mathrm{~cm}$ at the thinner end and longer than $0.3 \mathrm{~m}$. Field measurements were carried out in the period from 2004 to 2011.

\section{Data analysis - Analiza podataka}

Height curves for all studied stands were obtained by Prodan's function:

$$
h=\frac{d^{2}}{a+b d+c d^{2}}+1.30
$$

where $h$ is the height and $d$ diameter at breast height.

Diameter diversity was calculated using the Gini index and the Coefficient of variation, while the height diversity was calculated using the Coefficient of variation.

The Gini coefficient $G d b h$ is defined as the area between the line of perfect equality (the diagonal) and the Lorenz curve, expressed as the proportion of the area under the diagonal (Weiner \& Solbrig, 1984). When measuring tree size diversity, the Gini coefficient requires trees to be ranked by size and it quantifies the deviation from perfect equality when all trees are of equal size. Diameter diversity is measured on a scale from 0 to 1 , where the $G d b h$ would be 0 if all trees in a stand were of equal diameter at breast height, while it would equal 1 if all trees but one had a value of 0 (O'Hara et al. 2007). Solomon \& Gove (1999) stated that the use of basal area or volume may provide a more accurate estimation of structural diversity than the use of the number of trees. In our research, the $G d b h$ was calculated using the data on the number of trees and their basal area per class of breast height diameter (O'Hara et al. 2007).

The Gini coefficient of sample plot structure is calculated using equation (2).

$$
G d b h=\frac{\sum_{j=1}^{n}(2 j-n-1) b a_{j}}{\sum_{j=1}^{n} b a_{j}(n-1)}, 0 \leq G d b h<1
$$

where:

$\mathrm{ba}_{\mathrm{j}}$ - represents basal area for a tree with rank $\mathrm{j}\left(\mathrm{m}^{2} \mathrm{ha} \mathrm{a}^{-1}\right)$;

$j$ - represents the rank of a tree in an ascending order from $1, \ldots, \mathrm{n}$;

$\mathrm{n}$ - represents the total number of trees;

The Gini coefficient of stand structure is calculated as an arithmetical mean of sample plot coefficients.
The Coefficient of variation of tree diameters (CVdbh \%) and heights $(\mathrm{CVh} \%)$ was calculated according to Sokal \& Rohlf (1981):

$$
C V d b h, h \%=\frac{\text { s.d. }}{\bar{X} d b h, h} * 100
$$

where s.d. is the standard deviation, and $\bar{X} d b h, h$ arithmetical mean of dbh and height.

Tree volume (volume of taper and branches over $3 \mathrm{~cm}$ in diameter) was determined using a regression equation (4) which was obtained from the analytical equalization of volume tables of beech trees in Serbia (Mirković 1969).

$$
v=0.2811817 d^{2.0415244} h^{1.1123098}
$$

Above-ground tree biomass $(B)$ was determined by the general regression equation (5) designed for the estimation of the total biomass of European beech trees (Wutzler et al. 2008).

$$
B=0.0523 d^{2.12} h^{0.655}
$$

where:

$\mathrm{m}$-represents total above-ground tree biomass (without leaves) in $\mathrm{kg}$,

$\mathrm{d}$ - represents tree diameter at breast height in $\mathrm{cm}$,

$\mathrm{h}$ - represents tree height in $\mathrm{m}$

Root biomass was obtained by the regression equation (6) for beech forests in Serbia (Koprivica et al. 2012).

$$
B r=0.429475+0.182227 B-0.000047499 B^{2}
$$

where:

$\mathrm{Br}$ - below-ground tree biomass (roots) in $\mathrm{t} \mathrm{ha}^{-1}$, $\mathrm{B}$ - above-ground tree biomass in $\mathrm{tha}^{-1}$

The total biomass $(B t)$ was obtained as the sum of the biomass above and below the ground.

Above-ground carbon stock $(C)$ was determined using the general regression equation (7) intended for the assessment of carbon stock in European beech (Joosten et al. 2004).

$$
C=0.023806419 d^{2.1569} h^{0.66338}
$$

The carbon stored in roots was determined by multiplying its biomass by a factor of 0.5 (IPCC, 2003).

The average volume, biomass and carbon stock per ha of the managed beech stands were obtained from the data collected on the sample plots. In the virgin beech stands of Danilova kosa and Vinatovača, a complete inventory was performed and the total volume, biomass and carbon stock were calculated. 
In Kukavica virgin forest, seven sample plots were established. Therefore, when calculating the mean and standard deviation of the observed characteristics (volume, biomass, carbon) in a sample of all sample plots ( $\mathrm{n}=7, \mathrm{x}_{\mathrm{i}}$-size of the observed characteristics per hectare) weights were used. Weights are surface plots (pi). The arithmetic mean was obtained by formula (8), and the variance by formula (9).

$$
\begin{gathered}
\bar{x}=\frac{\sum p_{i} x_{i}}{\sum p_{i}} \\
s^{2}=\frac{n}{n-1} \frac{\sum p_{i}\left(x_{i}-\bar{x}\right)^{2}}{\sum p_{i}}
\end{gathered}
$$

To test the statistical significance of the differences in the proportions, arithmetic means and the variance of the observed characteristics of the managed and virgin beech forests $\mathrm{Z}$ and $\mathrm{F}$ test were used. $\mathrm{Z}$ test was used to test the null hypothesis about the equality of proportions and arithmetic means, while $\mathrm{F}$ test was used to determine the differences between the variances. Two large and independent samples were used for the testing. From the statistical point of view, the problem was that the study sample plots were not always of the same size. The managed beech forest plots were 0.05 ha in size and there was a total of $n_{1}=127$. Kukavica virgin forest had sample plots of 0.15 ha to 0.79 ha in

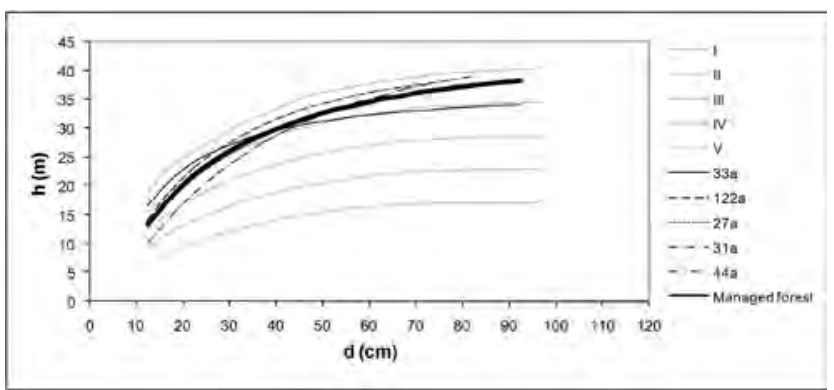

Figure 2. Height curves of the managed stands (I-V are height curves for site classes)

Slika 2. Visinske krivulje sastojina gospodarskog tipa (I-V su opće visinske krivulje po bonitetima)

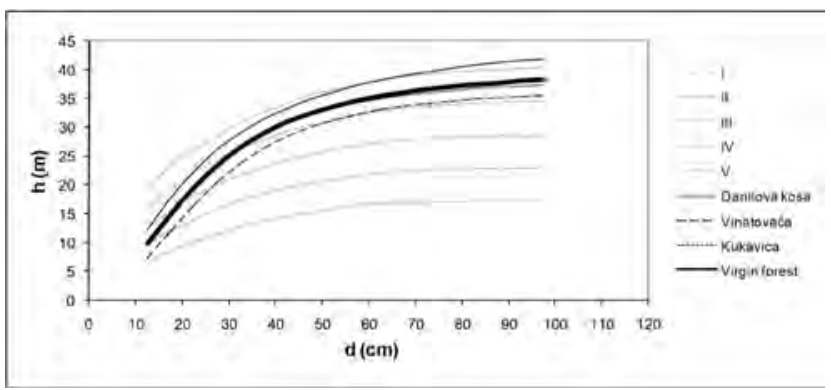

Figure 3. Height curves of the virgin stands (I-V are height curves for site classes)

Slika 3. Visinske krivulje sastojina prašumskog tipa (I-V su opće visinske krivulje po bonitetima) size and there were seven of them. In Danilova kosa and Vinatovača virgin forests, a total survey was conducted, so it was assumed that each ha was a plot (totally $35 \mathrm{ha}$ ). Thus, the size of the second sample was $n_{2}=42$.

In order to facilitate statistical analysis, the data from all sample plots established in the managed forest and in $\mathrm{Ku}-$ kavica virgin forest were converted into hectares. So this conditional hectare was equated with an actual hectare in the virgin forests of Danilova kosa and Vinatovača. Thus, hectare was used as the basic unit of observation in both samples. The number of ha in the stand was used as the weight (frequency).

Stand quadratic mean diameter $(D g)$ and Lorey's mean height (HL) were calculated for all stands.

\section{RESULTS AND DISCUSSION REZULTATI I RASPRAVA}

\section{Height curves - Visinske krivulje}

Height curves show certain differences in the shape of curves and in the heights of thin trees (diameter of 10 to 30 $\mathrm{cm}$ ) in the managed (Fig. 2) and virgin forest stands (Fig. 3) in Serbia.

The shape of height curves is different in the diameter of 30 $\mathrm{cm}$ because the slope of the curve is higher in the virgin forest stands than in the managed stands. The height of medium-thick and thick trees is nearly uniform. Comparing height curves in Uholka virgin forest in Ukraine and managed uneven-aged beech forest Sihlwald in Switzerland, Commarmot et al. (2005) found no significant differences in the relation of height to diameter at breast height in diameters from 8 to $86 \mathrm{~cm}$ (maximum diameter of beech in Sihlwald). They also observed that height curves had a similar shape.

Comparing Figures 2 and 3 we can conclude that thinner trees in the virgin stands attain $3.4 \mathrm{~m}$ (diameter $15 \mathrm{~cm}$ ) and $1.8 \mathrm{~m}$ (diameter $25 \mathrm{~cm}$ ) lower heights, while the average difference in the height of medium-thick and thick trees (diameter from 30 to $100 \mathrm{~cm}$ ) is $+/-0.5 \mathrm{~m}$.

\section{Structural diversity - Strukturna raznolikost}

The diameter distribution of the managed stands (Fig. 4) can roughly be identified as the distribution characteristic for selective managed stands. Diameter distribution of the virgin stands Danilova kosa and Vinatovača can be roughly described as the virgin forest stand structure (Fig. 5). The largest number of trees are in the diameter classes of 10 to $25 \mathrm{~cm}$ and 50 to $80 \mathrm{~cm}$. Similar results in the study of diameter distribution of virgin forest stands in Eastern, Central and Southern Europe were obtained by other authors (Meyer et al. 2003, Commarmot et al. 2005, Drössler \& Lüpke 2007, Bilek et al. 2011, Kucbel et al. 2012). Partially different shape of Diame- 


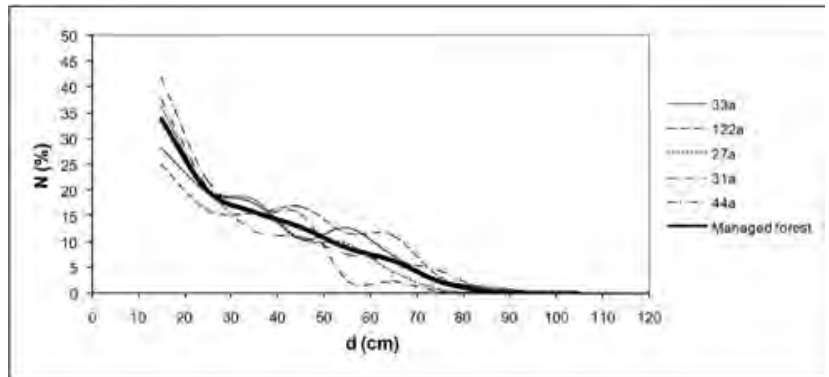

Figure 4. Diameter distribution of the managed stands Slika 4. Debljinska struktura sastojina gospodarskog tipa

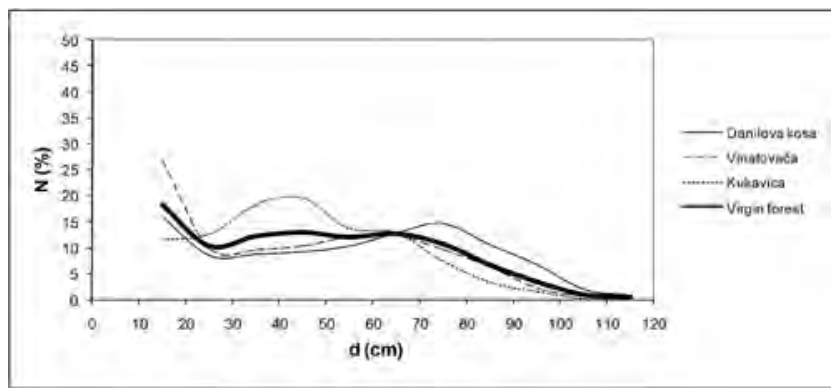

Figure 5. Diameter distribution of the virgin stands Slika 5. Debljinska struktura sastojina prašumskog tipa

ter distribution of Kukavica virgin forest compared to other two beech virgin forests is due to the fact that Kukavica is the youngest forest reserve and the time that has passed since it was declared a reserve was not long enough to develop all structural features of a virgin forest (Fig. 5).

The differences in the values of the Gini coefficient are random with a probability of $82 \%$ and there is also a small difference in the Coefficients of variation of tree diameters and heights (Tab. 2). The Gini coefficient $\bar{G} d b h$ was in the range from 0.49 to 0.57 in the managed stands and from 0.45 to 0.52 in the virgin stands. Bilek et al. (2011) found an average $\bar{G} d b h$ of 0.22 in five managed stands (even-aged structure) in Central Bohemia, while two virgin stands had the coefficient between 0.67 and 0.75 . Significant differences in $\bar{G} d b h$ between the virgin stands of Central Bohemia and Serbia can be affected by the difference in the lower limit of diameter at breast height which was $7 \mathrm{~cm}$ in Central Bohemia and $10 \mathrm{~cm}$ in Serbia.

Coefficient of variation of tree diameters $(C V d b h \%)$ is in the range from 50.8 to $59.5 \%$ in the managed stands, while it ranges from 47.1 to $57.5 \%$ in virgin stands. Bilek et al. (2011) found an average CVdbh\% of $21.0 \%$ in the managed stands, and between 80.3 and $109.6 \%$ in two virgin stands. Coefficient of variation of tree heights $(\mathrm{CVh} \%)$ is in the range from 21.7 to $41.1 \%$ in the managed stands and from 27.4 to $30.8 \%$ in virgin stands.

The Gini Coefficient $\bar{G} d b h$ and the Coefficient of variation of tree diameters $(\mathrm{CVdbh} \%)$ show high diameter diversity
Table 2. Average values of the Gini coefficient $\bar{G} d b h$ and the Coefficient of variation of tree diameters (CVdbh \%) and heights (CVh \%)

Tablica 2. Prosječne vrijdnosti Gini koeficijenta $\bar{G} d b h$ i koeficijenta varijacije promjera stabala (CVdbh \%) i visine (CVh \%)

$\begin{array}{lcccc}\text { Stand } & \begin{array}{c}\text { Weight } \\ \text { (ha) }\end{array} & \text { Gdbh } & \text { CVdbh \% } & \text { CVh \% } \\ \text { 33a } & 23 & 0.52 & 52.50 & 21.69 \\ \text { 122a } & 29 & 0.49 & 51.31 & 31.45 \\ \text { 27a } & 20 & 0.52 & 53.20 & 34.50 \\ \text { 31a } & 32 & 0.51 & 50.76 & 41.12 \\ \text { 44a } & 23 & 0.57 & 59.50 & 34.70 \\ \text { Managed forest } & 127 & 0.52 & 53.17 & 33.19 \\ \text { Danilova kosa } & 7 & 0.45 & 49.73 & 27.39 \\ \text { Vinatovača } & 28 & 0.52 & 57.51 & 30.68 \\ \text { Kukavica } & 7 & 0.46 & 47.07 & 30.79 \\ \text { Virgin forest } & 42 & 0.50 & 54.47 & 30.15\end{array}$

* ha is the number of conditionally and actually measured hectares in stands

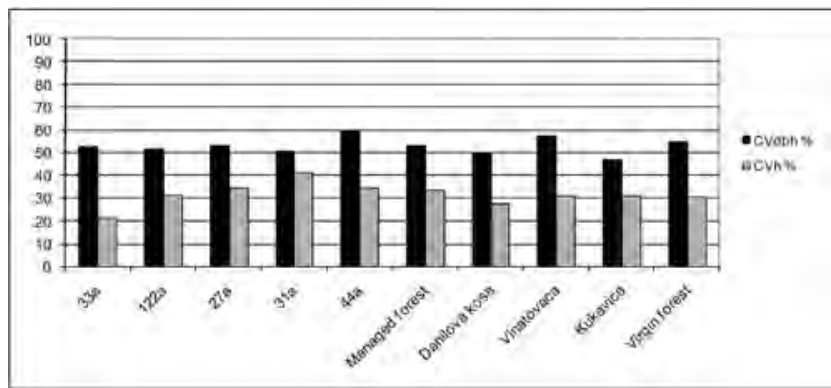

Figure 6. Comparison of the coefficients of variation of tree diameters (CVdbh \%) and heights (CVh \%)

Slika 6. Komparacija vrijednosti koeficijenta varijacije promjera stabala (CVdbh \%) i visina (CVh \%)

in all studied stands. Diameter diversity is slightly larger in the managed stands than in the virgin stands. This rule also applies to height diversity. As expected, diameter diversity is much more pronounced than height diversity in all studied stands.

The relative ratio of the coefficient of variation of tree diameters $(C V d b h \%)$ and the coefficient of variation of tree heights $(C V h \%)$ shows a significant deviation in the managed type of stands - from 1.23 to 2.42 , while it is more uniform in the virgin type of stands and ranges from 1.53 to 1.87. This relationship shows that diameter and height diversities in beech forests in Serbia aren ' $t$ strongly correlated and the knowledge of one of them doesn 't enable estimation of the other one (Fig. 6). This statement is confirmed by correlation analysis which provided a low correlation coefficient of 0.12 .

\section{Slenderness coefficient - Koeficijent vitkosti}

The ratio of height to diameter at breast height $h / d_{b h}$ (Slenderness coefficient) have on average higher values in the managed stands than in the virgin stands (Tab. 3). We 
Table 3. Slenderness coefficients in the studied stands Tablica 3. Koeficijent vitkosti u istraživanim sastojinama

\begin{tabular}{|c|c|c|c|c|c|c|c|c|c|c|}
\hline \multirow[b]{2}{*}{$\mathrm{h} / \mathrm{d}_{\mathrm{bh}}$} & \multicolumn{10}{|c|}{ Stand } \\
\hline & $33 a$ & $122 a$ & $27 a$ & $31 a$ & $44 a$ & $\begin{array}{l}\text { Managed } \\
\text { forest }\end{array}$ & $\begin{array}{l}\text { Danilova } \\
\text { kosa }\end{array}$ & Vinatovača & Kukavica & $\begin{array}{l}\text { Virgin } \\
\text { forest }\end{array}$ \\
\hline Minimum & 0.34 & 0.44 & 0.47 & 0.36 & 0.41 & 0.34 & 0.34 & 0.30 & 0.32 & 0.30 \\
\hline Maximum & 1.92 & 2.22 & 1.52 & 1.57 & 1.79 & 2.22 & 1.65 & 1.21 & 1.63 & 1.65 \\
\hline Average & 0.93 & 0.88 & 0.89 & 0.81 & 0.90 & 0.88 & 0.71 & 0.55 & 0.70 & 0.60 \\
\hline
\end{tabular}

Table 4. Maximum tree size values in the studied stands

Tablica 4. Maksimalne vrijednosti veličine stabla u istraživanim sastojinama

\begin{tabular}{|c|c|c|c|c|c|c|c|c|c|c|}
\hline \multirow{2}{*}{$\begin{array}{l}\text { Maximum } \\
\text { size }\end{array}$} & \multicolumn{10}{|c|}{ Stand } \\
\hline & $33 a$ & $122 a$ & $27 a$ & $31 a$ & $44 a$ & $\begin{array}{l}\text { Managed } \\
\text { forest }\end{array}$ & $\begin{array}{c}\text { Danilova } \\
\text { kosa }\end{array}$ & Vinatovača & Kukavica & $\begin{array}{l}\text { Virgin } \\
\text { forest }\end{array}$ \\
\hline $\mathrm{dbh}(\mathrm{cm})$ & 92 & 82 & 72 & 73 & 81 & 80 & 120 & 118 & 105 & 114 \\
\hline $\mathrm{h}(\mathrm{m})$ & 44.1 & 44.5 & 38.8 & 43.7 & 44.0 & 43.0 & 53.7 & 47.1 & 44.0 & 48.3 \\
\hline
\end{tabular}

assume that this difference is mainly caused by the large participation of thinner trees in managed forests. These trees are characterized by higher values of Slenderness coefficient in comparison to thicker trees.

Korpel et al. (1991) gave the critical value of $h / d_{b h}$ ratio for beech in the range from 1.8 to 2.2 in the context of the stability of trees. In all studied stands this ratio was on average significantly lower than the critical values. Only two managed stands had this ratio in the suggested critical value range. In the beech stands of virgin type in Central Bohemia similar results were obtained - from 0.28 to 1.89 (Bilek et al. 2011). Drössler \& Lüpke (2007) noticed that the trees of the lower and middle storey in beech virgin forest Havešova in Slovakia had an average of 1.39 and the trees of the upper storeys an average of 0.67 .

\section{Maximum dimensions of trees - Maksimalne dimenzije stabala}

The maximum tree diameters at breast height are from 72 to $92 \mathrm{~cm}$ ( $80 \mathrm{~cm}$ on average) in the managed stands and from 105 to $120 \mathrm{~cm}$ (114 cm on average) in the virgin stands. Large-sized standing dead trees have dbh from 94 to $122 \mathrm{~cm}$ in the virgin stands. The maximum tree height is from 38.8 to $44.5 \mathrm{~m}$ ( $43 \mathrm{~m}$ on average) in the managed stands and from 44.0 to $53.7 \mathrm{~m}$ ( $48.3 \mathrm{~m}$ on average) in the stands of virgin type. In the virgin forest stand of Danilova kosa there are two trees with the height over $50 \mathrm{~m}$ (50.7 and $53.7 \mathrm{~m}$ ) and diameters between 115 and $120 \mathrm{~cm}$ (Tab. 4). The dimensions obtained in virgin forests in Serbia are similar to the dimensions presented in various studies on beech virgin forests in the area of Central, Eastern and Southern Europe. Meyer et al. (2003) found maximum diameters of 99, 122 and $115 \mathrm{~cm}$ in Merdita, Puka and Rajca virgin forests in Albania. Turcu \& Stetca (2006) measured the largest diameter of $126.4 \mathrm{~cm}$ and a height of $51.7 \mathrm{~m}$ in
Izvoarele Nerei beech virgin forest in Romania. In seven beech reserves in Slovakia the largest diameters measured in the last 40 years were from 81.5 to $121.0 \mathrm{~cm}$ (Kucbel et al. 2012). In two virgin beech stands in Central Bohemia the largest diameters ranged from 108.2 to $110.2 \mathrm{~cm}$ and the maximum heights measured 42 to $44 \mathrm{~m}$, while in the managed even-aged beech stands diameters were from 72.2 to $102.1 \mathrm{~cm}$ and the height was $49 \mathrm{~m}$ (Bilek et al. 2011). Commarmot et al. (2005) found the biggest diameter of 132.6 and a height of about $50 \mathrm{~m}$ in the virgin forest of Uholka in Ukraine. Korpel (1995) measured a maximum height of $49 \mathrm{~m}$ in Havešova forest reserve in Slovakia. In Hrončokovsky Grun reserve in central Slovakia Holeksa et al. (2009) found a maximum height of $47 \mathrm{~m}$. Drössler and Lüpke (2007) noticed a maximum diameter of $127 \mathrm{~cm}$ and a height of about $50 \mathrm{~m}$, with an extreme height of $56 \mathrm{~m}$ in beech virgin forest in Slovakia. Petritan et al. (2012) found that beech trees in natural mixed forests of oak and beech in western Romania had diameters up to $102 \mathrm{~cm}$ and heights of up to $51 \mathrm{~m}$.

\section{Stand density and productivity - Sastojinska gustoća i produktivnost}

Table 5 shows the data on the most important forest estimation elements of the studied beech stands, and average values and variability of these elements in the managed and virgin stands.

Using the $\mathrm{F}$ test the differences were determined in the variability of the average number of trees $(\mathrm{N})$, basal area $(\mathrm{G})$, volume $(\mathrm{V})$, total biomass $(\mathrm{Bt})$ and total carbon stock $(\mathrm{Ct})$, stand quadratic mean diameter $(\mathrm{Dg})$, standing dead wood volume (Vs), lying dead wood volume (Vl) and total dead wood volume $(\mathrm{Vt})$ per ha for two types of stands statistically significant at $2 \%$ risk level. However, the difference in the variability Lorey's mean height (HL) is statistically random. 
Table 5. Forest estimation elements of the studied beech stands

Tablica 5. Procjena taksacijskih elemenata istraživanih bukovih sastojina

\begin{tabular}{|c|c|c|c|c|c|c|c|c|c|c|c|}
\hline \multirow[b]{2}{*}{ Stand } & \multirow{2}{*}{$\begin{array}{l}\text { Weight } \\
\text { (ha) }\end{array}$} & \multicolumn{7}{|c|}{ Living wood } & \multicolumn{3}{|c|}{ Dead wood } \\
\hline & & $\begin{array}{c}\mathrm{N} \\
\left(\mathrm{Nha}^{-1}\right)\end{array}$ & $\begin{array}{c}G \\
\left(m^{2} h^{-1}\right)\end{array}$ & $\begin{array}{c}V \\
\left(m^{3} h a^{-1}\right)\end{array}$ & $\begin{array}{c}\mathrm{Bt} \\
\left(\mathrm{Mg} \mathrm{ha}^{-1}\right)\end{array}$ & $\begin{array}{c}\mathrm{Ct} \\
\left(\mathrm{Mg} \mathrm{ha}^{-1}\right)\end{array}$ & $\begin{array}{l}\mathrm{Dg} \\
(\mathrm{cm})\end{array}$ & $\begin{array}{l}\mathrm{HL} \\
(\mathrm{m})\end{array}$ & $\begin{array}{c}\text { Vs } \\
\left(\mathrm{m}^{3} \mathrm{ha}^{-1}\right)\end{array}$ & $\begin{array}{c}\text { VI } \\
\left(\mathrm{m}^{3} \mathrm{ha}^{-1}\right)\end{array}$ & $\begin{array}{c}\mathrm{Vt} \\
\left(\mathrm{m}^{3} \mathrm{ha}^{-1}\right)\end{array}$ \\
\hline $33 a$ & 23 & 274 & 33.42 & 522.49 & 393.18 & 194.78 & 39.4 & 31.0 & 2.41 & 24.53 & 26.94 \\
\hline $122 a$ & 29 & 214 & 29.03 & 503.58 & 363.34 & 179.83 & 41.6 & 33.7 & 7.10 & 2.63 & 9.73 \\
\hline $27 a$ & 20 & 259 & 23.10 & 353.76 & 261.09 & 128.77 & 33.7 & 30.2 & 5.88 & 8.3 & 14.18 \\
\hline $31 \mathrm{a}$ & 32 & 301 & 21.53 & 290.84 & 228.66 & 112.54 & 30.2 & 28.0 & 9.94 & 16.54 & 26.48 \\
\hline $44 a$ & 23 & 294 & 31.04 & 502.03 & 370.88 & 183.61 & 36.7 & 32.1 & 6.98 & 3.32 & 10.30 \\
\hline Managed & $\mathrm{AM}^{*}$ & 268 & 27.37 & 429.53 & 320.07 & 158.23 & 36.2 & 30.9 & 6.46 & 11.06 & 17.53 \\
\hline forest $n_{1}=127$ & $\mathrm{SD}^{* *}$ & 32.89 & 4.60 & 97.57 & 67.20 & 33.58 & 4.31 & 2.06 & 2.43 & 8.37 & 10.80 \\
\hline Danilova kosa & 7 & 123 & 36.24 & 760.09 & 517.31 & 258.52 & 61.1 & 39.2 & 107.76 & 67.01 & 174.77 \\
\hline Vinatovača & 28 & 175 & 36.27 & 611.31 & 455.23 & 227.47 & 51.4 & 32.3 & 87.33 & 41.74 & 129.07 \\
\hline Kukavica & 7 & 201 & 39.31 & 695.31 & 496.78 & 247.23 & 50.2 & 33.8 & 19.66 & 22.67 & 42.33 \\
\hline Virgin forest & $\mathrm{AM}^{*}$ & 170 & 36.77 & 650.11 & 472.50 & 235.94 & 52.8 & 33.7 & 71.58 & 43.81 & 115.39 \\
\hline $\mathrm{n}_{2}=42$ & $S D^{* *}$ & 23.34 & 1.14 & 57.97 & 25.13 & 12.41 & 3.73 & 2.52 & 37.65 & 18.16 & 54.93 \\
\hline F statistic & & 14.7 & 9.4 & 13.2 & 13.2 & 13.7 & 23.6 & 4.3 & 11.1 & 9.0 & 11.5 \\
\hline P-Value & & 0.01 & 0.02 & 0.01 & 0.01 & 0.01 & 0.00 & 0.09 & 0.02 & 0.02 & 0.01 \\
\hline Z statistics & & 2.4 & -4.1 & -3.2 & -4.0 & -4.0 & -3.2 & -0.7 & -1.4 & -1.5 & -1.5 \\
\hline P-Value & & 0.01 & 0.00 & 0.00 & 0.00 & 0.00 & 0.00 & 0.23 & 0.08 & 0.07 & 0.07 \\
\hline
\end{tabular}

*AM - Arithmetic mean; **SD - Standard deviation

Table 6. Forest estimation elements of virgin beech forests in Central, Eastern and Southern Europe Tablica 6. Taksacijski elementi bukovih prašuma u srednjoj, istočnoj i južnoj Europi

$\begin{array}{lccccc}\text { Authors } & \text { Reserve } & \text { N } & \text { G } & \text { V } & \text { Dg } \\ \left(\mathrm{N} \mathrm{ha}^{-1}\right) & \begin{array}{c}\left.\mathrm{G} \mathrm{a}^{-1}\right) \\ \left(\mathrm{m}^{2} \mathrm{ha}^{-1}\right)\end{array} & 38.4 & 651.9 & 46.0 \\ \text { Drinić 1957 } & \text { Donja Drinjača } & 231 & 40.5 & 662.1 & 44.4 \\ \text { Drinić 1957 } & \text { Donja Drinjača } & 262 & 39.7 & 700.0 & 49.2 \\ \text { Mayer \& Reimoser 1978 } & \text { Dobra } & 209 & 45.6 & 780.7 & 42.0 \\ \text { Meyer et al. 2003 } & \text { Puka } & 325 & 43.4 & 807.4 & 37.7 \\ \text { Meyer et al. 2003 } & \text { Rajca } & 390 & 38.5 & 770.0 & 48.0 \\ \text { Commarmot et al. 2005 } & \text { Uholka } & 219 & 35.0 & 716.0 & 38.8 \\ \text { Drössler \& Lüpke 2007 } & \text { Havešova } & 290 & 35.6 & 707.2 & 48.8 \\ \text { Bilek et al. 2011 } & \text { Beechwood of Voderady } & 203 & * 38.2 & * 681.0 & * \\ \text { Kucbel et al. 2012 } & \text { Badin } & * 269 & * 39.5 & * 74.0 & * 42.5 \\ \text { Kucbel et al. 2012 } & \text { Rožok } & * 270 & & & * 43.2\end{array}$

*Average for five periodical measurments from 1961 to 2010

Using the $\mathrm{Z}$ test the difference between the average values of the most of studied estimation elements were shown as statistically significant or it is near the threshold of statistical significance. Exception is again Lorey's mean height (HL) (Tab. 5).

The comparison of stand estimation elements of the virgin forests in Serbia (Tab. 5) with the studied virgin forests in Central, Eastern and Southern Europe on the most productive sites (Tab. 6) showed that the biggest differences were in the number of trees per hectare and the stand quadratic mean diameter. The number of trees in the stands in Serbia ranged from 123 to 201, while in the stands in Central, Eastern and Southern Europe it ranged between 203 and 390. This analysis should take into account that the lower limit of diameter at breast height was not the same in all studies, which affected the total number of trees (in our study 10 $\mathrm{cm}$ and in majority of other studies 5 or $7 \mathrm{~cm}$ ). The value of the lower limit of diameter at breast height in our study somewhat increased the values of Stand quadratic mean diameter. The stand quadratic mean diameter in Serbia was from 50.2 to $61.1 \mathrm{~cm}$ while in the stands in Central, Eastern and Southern Europe it ranged from 37.7 to $49.2 \mathrm{~cm}$. Basal area and volume per hectare were approximately the same. In 86 European beech forest reserves across Europe the mean value of deadwood volume was found to be $130 \mathrm{~m}^{3}$ ha- 1 and it varied from almost zero to $550 \mathrm{~m}^{3}$ ha- 1 (Christensen et al. 2005). In our research, we found that in $\mathrm{Da}$ nilova kosa, Vinatovača and Kukavica the volume of dead wood was about $115 \mathrm{~m}^{3}$ ha-1 (Tab. 5). In our opinion, small volumes of dead wood in Kukavica virgin forest is due to 
its relatively short history under state protection (thirty years). The managed forest deadwood volume was 10-20 times smaller than in the virgin forests. The research in Finland, Sweden, Germany, France, Belgium and Switzerland showed that the average volume of dead wood was less than $10 \mathrm{~m}^{3}$ ha- 1 (Christensen et al. 2005). Compared to this result, the determined average volume of dead wood per hectare in specific managed beech forests in Serbia (Koprivica et al. 2013a) was almost twice as high, which can be assessed as important for the conservation of the general biological diversity.

In specific managed beech forests in Serbia other important research studies were conducted. Matović (2012) found that, in addition to significant dimensional diversity, these forests were characterized by heterogeneous spatial and age structure. Trees were usually randomly distributed in space, although they were often grouped in clumps and in a regular pattern. The age structure of these forests was strongly pronounced and represented by trees aged from one year to over 400 years in some stands. Koprivica et al. (2012, 2013b) found that the average values of basal area, volume, volume increment, biomass and carbon in these forests were relatively high and that these forests preserved their production potential.

The research conducted within this study and previous studies of the same authors suggest that although these forests have often been under inadequate and inconsistent forest management, they have preserved their production potential, structural diversity and naturalness. Moreover, in the context of the proclaimed approach to forest management in the future in Europe, these forests can be considered much closer to the original natural forests by many criteria. In comparison to other beech forests in Europe that are predominantly even-aged and more homogeneous in structure, managed forests in Serbia are uneven-aged and spatially heterogeneous.

It is important to emphasize that major natural disturbances such as wind or ice forest storms haven 't made any greater damage in managed beech forest in Serbia so far. Hanewinkel et al. (2014) found that uneven-aged forests had significantly higher resistance to heavy storms than evenaged forests. Furthermore, no significant insect calamities, epiphytotic attacks, fires and visible negative impact of longterm drought have been observed in beech forests in Serbia, which is due to their marked uneven-aged structure. We should bear in mind that Serbia is relatively close to the European Mediterranean Basin, one of the world's climate change hotspots (Luterbacher et al. 2012). In the neighboring Hungary, Lakatos and Molnar (2009) found a mass dieback of beech forests in even-aged beech forests in the period of drought (2000-2004). Using the regional climate model and the biometeorological index, Stojanović et al. (2013) found out that by the end of the twenty-first century the majority of existing beech forest in Serbia may be beyond their $20^{\text {th }}$ century ecological niches. In this context, it is of critical importance to implement adequate management measures to conserve the pronounced structure, uneven-age character and naturalness of beech forests in order to create better conditions for natural adaptation of these forests to the anticipated climate change in the future. Brang et al. (2014) defined six adaptation principles to climate change ("increase tree species richness, increase structural diversity, maintain and increase genetic variation within tree species, increase resistance of individual trees to biotic and abiotic stress, replace high-risk stands and keep average growing stocks low") and concluded that they are already largely contained in close-to-nature forestry.

\section{CONCLUSIONS}

\section{ZAKLJUČCI}

Having compared the stand structure of managed and virgin stands on the best beech sites in Serbia, as well as their stand structure with the beech virgin forests in Central, Eastern and Southern Europe in accordance with the aims of this research, the following conclusions can be drawn:

1. The impact of previous forest management in beech high forests in Serbia on Structural diversity of trees is twofold. The greatest differences were found in the dimensions of the largest trees in the managed forests and in the stands of virgin character (dbh and heights). Certain differences were found in the shape of Height curves and Diameter distribution and the values of Slenderness coefficient. However, the Gini index and the Coefficient of variation show that the managed beech forests in Serbia substantially preserve Structural diversity, which is very important for these forests from the aspect of low tree species diversity and maintenance of the overall biodiversity.

2. The impact of previous management on the change in the average value of the forest estimation elements of managed beech high forests in Serbia in comparison to the virgin forests is clearly pronounced and statistically significant regarding production characteristics.

3. Comparison of forest estimation elements of stands of the virgin forest type in Serbia on the most productive sites with the equivalent forest stands in Central, Eastern and Southern Europe showed that the biggest differences were in the number of trees per hectare and the stand quadratic mean diameter. Basal area and volume and the volume of dead wood per hectare were quite similar.

4. The existing environmental stability of the managed beech forests in Serbia in the near past and present (after severe droughts) leads to the general conclusion that closeto-nature forestry may provide long-term conservation of these forests in the future within the limits of their current range in European terms. 


\section{ACKNOWLEDGMENTS ZAHVALA}

This paper was realized as a part of the project "Studying climate change and its influence on the environment: impacts, adaptation and mitigation" (III43007) financed by the Ministry of Education and Science of the Republic of Serbia.

\section{REFERENCES}

\section{LITERATURA}

- Benecke, U., 1996: Ecological silviculture: the application of ageold methods. New Zealand Forestry 41: 27-33.

- Bilek, L., J. Remes, D. Zahradnik, 2011: Managed vs. unmanaged. Structure of beech forest stands (Fagus sylvatica L.) after 50 years of development, Central Bohemia. Forest Systems 20(1): 122-138.

- Bradshaw, R., P. Gemmel, L. Bjorkman, 1994: Development of nature-based silvicultural models in southern Sweden: The scientific background. Forestry and Landscape Research 1: 95-110.

- Brang, P., P. Spathelf, J.B. Larsen, J. Bauhus, A. Bončina, C. Chauvin, L. Droessler, C. Garcia-Guemes, C. Heiri, G. Kerr, M.J. Lexer, B. Mason, F. Mohren, U. Muehlethaler, S. Nocentini, M. Svoboda, 2014: Suitability of close-to-nature silviculture for adapting temperate European forests to climate change. Forestry 87:492-503.

- Commarmot, B., H. Bachofen, Y. Bundziak, A. Burgi, B. Ramp, Y. Shparyk, D. Sukhariuk, R. Viter, A. Zingg, 2005: Structure of virgin and managed beech forests in Uholka (Ukraine) and Sihlwald (Switzerland): a comparative study. Forest Snow and Landscape Research 79: 45-56.

- Christensen, M., K. Hahn, E.P. Mountford, P. Odor, T. Standovar, D. Rozenbergar, J. Diaci, S. Wijdeven, P. Meyer, S. Winter, T. Vrska 2005: Deadwood in European beech (Fagus sylvatica) forest reserves. Forest Ecology and Management 210: 267-282.

- Diaci, J. ed., 1999: Virgin forests and forest reserves in Central and East European countries: history, present status and future development. Proceedings of the invited lecturers' reports presented at the COST E4 management committee and working groups meeting in Ljubljana, Slovenia, Ljubljana, 25 - 28 April 1998. Department of Forestry and Renewable Forest Resources - Biotechnical Faculty, Ljubljana, pp. 173.

- Drinić, P., 1957: Taksacioni elementi bukovih sastojina prašumskog tipa u Donjoj Drinjači [Structural elements of European beech virgin stands in Donja Drinjača]. Radovi Poljoprivredno-Šumarskog fakulteta 2: 105-140. [In Serbian]

- Drössler, L., B.V. Lüpke, 2007: Bestandesstruktur, Verjüngung und Standortfaktoren in zwei Buchenurwald-Reservaten der Slowakei [Stand structure, regeneration and site conditions in two virgin beech forest reserves in Slovakia]. Allgemeine Forst und Jagdzeitung 178 (7/8): 121-135. [In German]

- Franklin, J.F., 1989: Toward a new forestry. American Forests 95 (11/12): 37-44.

- Gayer, K., 1886: Der gemischte Wald [The Mixed Forest]. Seine Begründung und Pflege, insbesondere durch Horst - und Gruppenwirtschaft. Verlag Paul Parey, Berlin, 168 pp.

- Hanewinkel, M., T. Kuhn, H. Bugmann, A. Lanz, P. Brang, 2014: Vulnerability of uneven-aged forests to storm damage. Forestry 87:525-534.
- Holeksa, J., M. Saniga, J. Szwagrzyk, M. Czerniak, K. Staszynska, P. Kapusta, 2009: A giant tree stand in the West Carpathians-An exception or a relic of formerly widespread mountain European forests? Forest Ecology and Management 257: 15771585.

- IPCC, 2003: Good practice guidance for land use, land-use change and forestry. Institute for Global Enviromental Strategies (IGES), Hayama, pp. 1-509.

- Joosten, R., J. Schumacher, C. Wirth, A. Schulte, 2004: Evaluating tree carbon predictions for beech (Fagus sylvatica L.) in western Germany. Forest Ecology and Management 189: 87-96.

- Koprivica, M., B. Matović, M. Vučković, B. Stajić, V. Čokeša, 2012: Estimates Biomass and Carbon stock in Beech high Forests in Serbia, International Scientific Conference, Forests in the Future, Sustainable Use, Risks and Challenges, Invitation papers, Institute of Forestry, Belgrade, Serbia, pp. 17-30.

- Koprivica, M., B. Matović, S. Stajić, V. Čokeša, Đ. Jović, 2013a: Dead wood in managed beech forests in Serbia. Šumarski list 137 (3/4): 173-183.

- Koprivica, M., B. Matović, M. Vučković, B. Stajić, 2013b: Estimation of biomass and carbon stock in uneven-aged beech stands in eastern Serbia. Allgemeine Forst und Jagdzeitung 184 (1/2): 17-25 .

- Korpel, Š., 1995: Die Urwälder der Westkarpaten [Virgin Forests of Western Carpatian ]. G. Fischer Verlag. Stuttgart, Jena, New York, pp. 329. [In German]

- Korpel, Š., J. Penáz, M. Saniga, V. Tesar, 1991: Pestovanie lesa [Silviculture]. Príroda, Bratislava. pp. 465. [In Slovakian]

- Kucbel, S., M. Saniga, P. Jaloviar, J. Vencurik, 2012: Stand structure and temporal variability in old-growth beech-dominated forests of the northwestern Carpathians: A 40-years perspective. Forest Ecology and Management 264: 125-133.

- Lakatos, F., M. Molnar, 2009: Mass mortality of beech on Southwest Hungary. Acta Silvatica et Lignaria Hungarica 5: 75-82.

- Leibundgut, H., 1959: Über Zweck und Methodik der Strukturund Zuwachsanalyse von Urwäldern [About purpose and methodology of structural- and growth analysis of virgin forests]. Schweizerische Zeitschrift für Forstwesen 110 (3): 111-124. [In German]

- Leibundgut, H., 1993: Europäische Urwälder [European Virgin Forests]. Verlag Paul Haupt. Bern, Stuttgart, pp. 260. [In German]

- Luterbacher. J., R. Garcia-Herrera, S. Akcer-On, et al., 2012: A review of 2000 years of paleoclimatic evidence in the Mediterranean. In: Lionello P (ed) The Climate of the Mediterranean region: From the past to the future. Elsevier, Amsterdam, pp. $87-185$

- Matović, B., 2012: Odnosi strukture, specijskog i ekosistemskog diverzizeta visokih bukovih šuma Srbije [Relationships between structure, species and ecosystem diversity of high beech forests in Serbia]. PhD thesis, Biološki fakultet, Beograd, pp. 247. [In Serbian]

- Mayer, H., F. Reimoser., 1978: Die Auswirkungen des Ulmensterbens im Buchen-Naturwaldreservat Dobra (Niederösterreichisches Waldviertel) [Effects of elm disease in the beech virgin forest of Dobra]. Forstwissenschaftliches Centralblatt 97 (1): 314-321. [In German]

- Meyer. P., V. Tabaku, B. von Lüpke, 2003: Die Struktur albanischer Rotbuchen-Urwälder-Ableitungen für eine naturnahe Buchenwirtschaft [Structural Characteristics of Albanian Beech 
(Fagus sylvatica L.) Virgin Forests - Deductions for Semi-Natural Forestry]. Forstwissenschaftliches Centralblatt 122: 47-58. [In German]

- Meyer, P., 2005: Network of strict forest reserves as reference system for close to nature forestry in Lower Saxony, Germany. Forest Snow and Landscape Research 79: 33-44.

- Miletić, Ž., 1930: Istraživanja o strukturi bukovih sastojina karaktera prašume [Research of structure of virgin European beech stands]. Šumarski list 54 (1): 2-9.

- Milin, Ž., 1954: Istraživanje elemenata strukture u bukovoj sastojini karaktera prašume u Južnom Kučaju [Research of structure of virgin European beech stand at Južni Kučaj]. Glasnik Šumarskog fakulteta 7: 37-72. [In Serbian]

- Mirković, D., 1969: Priručnik za određivanje zapremine i zapreminskog prirasta u bukovim sastojinama SR Srbije pri uređajnim radovima [Guidelines for estimation of volume and increment in European beech stands of Serbia during forest planning and management]. Institut za šumarstvo i drvnu industriju, Beograd, 147p. [In Serbian]

- Mlinšek, D., 1996: From clear-cutting to close-to-nature silviculture system. International Union of Forest Research Organisations. IUFRO News 25: 6-8.

- Möller, A., 1922: Der Dauerwaldgedanke: Sein Sinn und seine Bedeutung [The Dauerwald idea: its meaning and significance]. Verlag von Julius Springer, Berlin, 84 pp.

- O’Hara, K.L., H. Hasenauer, G. Kindermann, 2007: Sustainability in multi-aged stands: an analysis of long-term plenter systems . Forestry 80: $163-181$.

- Petritan, A.M., I.A. Biris, O. Merce, D.O. Turcu, I.C. Petritan, 2012: Structure and diversity of a natural temperate sessile oak (Quercus petraea L.) - European Beech (Fagus sylvatica L.) forest. Forest Ecology and Management 280: 140-149.

- Pommerening, A., S.T. Murphy, 2004: A review of the history, definitions and methods of continuous cover forestry with special attention to afforestation and restocking. Forestry 77(1): 27-44.
- Schnitzler, A., F. Borlea, 1998: Lessons from natural forests as keys for sustainable management and improvement of naturalness in managed broadleaved forests. Forest Ecology and Management 109: 293-303.

- Schütz, J.P., 1986: Charakterisierung des naturnahen Waldbaus und Bedarf an wissenschaflichen Grundlagen [Characterisation of close to nature forestry and the need for a scientific basis]. Schweizerische Zeitschrift für Forstwesen 137: 747-760. [In German]

- Sokal, R.R., F.J. Rohlf, 1981: Biometry. W.H. Freeman, New York, pp. 859.

- Solomon, D.S., J.H. Gove, 1999: Effects of uneven-age management intensity on structural diversity in two major forest types in New England . Forest Ecology and Management 114: 265-274.

- Stojanović, D., A. Kržič, B. Matović, S. Orlović, A. Duputie, V. Djurdjević, Z. Galic, S. Stojnic, 2013: Prediction of the European beech (Fagus sylvatica L.) xeric limit using a regional climate model: an example from southeast Europe. Agricultural and Forest Meteorology 176: 94-103

- Turcu, D.O., I.A. Stetca, 2006: The structure and dynamics of virgin beech forest ecosystems from "Izvoarele Nerei" reserveinitial results. In: Beech Sylviculture in Europe's Largest Beech Country. Proceedings of IUFRO Conference, 4-8 September 2006, Poiana Brasov, Romania, pp. 18-20.

- von Gadow, K., J. Nagel, J. Saborowski, 2002: Continuous Cover Forestry. Assessment, Analysis, Scenarios. Kluwer, Dordrecht, pp. 348.

- Weiner, J., O.T. Solbrig, 1984: The meaning and measurement of size hierarchies in plant populations. Oecologia 61:334-336.

- Wutzler, T., C. Wirth, J. Schumacher, 2008: Generic biomass functions for Common beech (Fagus sylvatica) in Central Europe: predictions and components of uncertainty. Canadian Journal of Forest Research 38: 1661-1675.

- Yorke, M., 1998: Continuous Cover Silviculture. An Alternative to Clear Felling. Continuous Cover Forestry Group, Bedford, pp. 52.

- * Republic Hydrometeorological Service of Serbia, http://www. hidmet.gov.rs/

\section{Sažetak}

U radu se prikazuju rezultati usporedbe strukturnih i proizvodnih karakteristika bukovih sastojina gospodarskog i prašumskog tipa u Srbiji. Istraživano je pet sastojina gospodarskog i tri sastojine prašumskog tipa. Cilj ovog istraživanja bio je utvrditi utjecaj prethodnog gospodarenja šumama na strukturnu raznolikost i proizvodne osobine visokih bukovih šuma u Srbiji. Istraživane sastojine nalaze se u planinskom rasponu od 400 do 1200 metara nadmorske visine u područjima gdje se nalaze najproduktivnije bukove šume u Srbiji (slika 1 i tablica 1). Strukturne karakteristike uspoređene su pomoću sljedećih parametara: visinske krivulje, debljinska struktura, Gini indeks, koeficijent varijacije, koeficijent vitkosti i maksimalne dimenzije dubećih živih i mrtvih stabla. Sastojinsku gustoću i produktivne osobine proučavane su pomoću sljedećih procijenenih taksacijskih elemenata: broj stabala, temeljnica, volumen, biomasa, zaliha ugljika, srednji promjer po temeljnici, Lorajeva srednja visina i volumen mrtvog drveta. Najveće razlike pronađene su u dimenzijama najvećih stabala u bukovim sasatojinama gospodarskog i prašumskog tipa (tablica 4). Određene razlike pronađene su u obliku visinskih krivulja i debljinskoj strukturi, i vrijednostima koeficijenta vitkosti (slike 2, 3, 4 i 5, i tablica 3). Međutim, Ginijev indeks i koeficijent varijacije pokazuju da su bukove sastojine gospodarskog tipa u Srbiji u velikoj mjeri sačuvale iskonsku strukturnu raznolikost (tablica 2 i slika 6). Razlike u prosječnim vrijednostima taksacijskih elemenata sastojina gospodarskog tipa visokih bukovih šumama u Srbiji u odnosu na sastojine prašumskog tipa su statistički značajne, što nam govori da je prethodno gospodarenje imalo značajan utjecaj na promjene u proizvodnim karakteristikama ovih šuma u Srbiji (tablica 5). 